\title{
Development of new precursors for one-part alkali activated geopolymer using industrial wastes
}

\author{
Monower Sadique $^{1 *}$, Abdullah Kadhim ${ }^{2}$, William Atherton ${ }^{1}$ and Patryk $\operatorname{Kot}^{1}$ \\ ${ }^{1}$ Department of Civil Engineering, Liverpool John Moores University, Peter Jost Centre, Byrom \\ Street, Liverpool L3 3AF, UK. \\ ${ }^{2}$ Department of Civil Engineering, Liverpool John Moores University, Henry \\ Cotton Building, Webster Street, Liverpool L3 2ET, UK. \\ * Monower Sadique, Email: m.m.sadique@1jmu.ac.uk
}

\begin{abstract}
Conventional two-part alkali activation has many drawbacks: the hazardous activating solution, which make it less friendly to handle, and the absence in long term availability of its main precursors such as fly ash and ground granulated furnace slag. This research aimed to develop a one-part alkali activated cement, which is free of chemical solutions. A blend of alumina-silicate rich materials with adequate alkaline content to minimise the limitations associated with the current (AAC) relating to source materials was utilised. At the same time, applying alternative activation methods such as thermo-mechanical activation, alkali-thermal activation or thermo-chemical activation of new (AAC) precursor were investigated. Materials were analysed in terms of their physical, chemical and metallurgical properties to understand the changes after thermal activation. Enhanced compressive strength were recorded from individual thermal activation of the materials at $450^{\circ} \mathrm{C}$ and $950^{\circ} \mathrm{C}$.
\end{abstract}

Keywords: One-part geopolymer, Alkali activation, Thermal activation.

\section{$1 \quad$ Introduction}

Recently, Alkali Activated Cement (AAC) or geopolymer cement has attracted global considerations for its high engineering and mechanical properties. Conventional two-part AAC are produced by activating solid alumina-silicate sources with alkali metal ( $\mathrm{Na}$ or $\mathrm{K}$ ) or alkaline earth $(\mathrm{Ca}$ or $\mathrm{Mg}$ ) hydroxide or silicate solution from a sequence of dissolution-reorientation-solidification reactions [1, 2]. However, this process of manufacturing has many drawbacks including chemicals handling difficulties and hazards from these solutions which in terms rising the impracticality of using these novel materials for in situ applications. Therefore the need for one-part dry AAC that just need water to create a binding material started to be very significant [3]. This means that AAC can be similar to OPC but with exceptional engineering and ecological properties. One-part AAC can be synthesized by providing sources of (alkali + silicate + aluminate) as solid powder form with utilizing various assisted activation methods such as thermal (calcination), mechanical (grinding) or combination of both methods. Widerange of alumina-silicate materials can be incorporated in the process including (natural 
and artificial) pozzolans and industrial (by-products and wastes). Sturm, Gluth [4] synthesised one-part Geopolymer mix by mixing calcined $\left(600{ }^{\circ} \mathrm{C}\right)$ Rice Husk Ash and solid sodium aluminate which was considered as activator in the system as it easily to dissolve on water. Therefore, water just added to the binder with a water/binder ratio 0.5 . The samples were cured in open moulds for an $80{ }^{\circ} \mathrm{C}$ to increase the reactivity of the mixtures. The obtained compressive strength was $30 \mathrm{Mpa}$ after one day curing. Alkaline source can be either ( $\mathrm{Na}, \mathrm{K}$ or $\mathrm{Ca}, \mathrm{Mg}$ ), however, past studies proved that using $\mathrm{CaO}$ or $\mathrm{Ca}(\mathrm{OH})_{2}$ can be alternative activators as these source are cheaper than $(\mathrm{NaOH}$ or $\mathrm{KOH})[5,6]$. Kim, Jun [6] used synthetic commercial $\mathrm{CaO}$ solid powder to create cement free binder with ground granulated blast furnace slag as $\mathrm{Si} / \mathrm{Al}$ source material. After comparing with $\mathrm{Ca}(\mathrm{OH})_{2}, \mathrm{CaO}$ activator was discovered to present developed mechanical properties with $53 \mathrm{MPa}$ strength of 56 days because of fabrication of additional C-S-H than $\mathrm{Ca}(\mathrm{OH})_{2}$.

In this research, attempts were targeting toward synthesise a dry one-part AAC utilising a waste material from quick lime production which is mostly rich of alkaline source $(\mathrm{CaO})$ instead of the commercial synthetic $\mathrm{CaO}$ chemical powder which was used by past studies. This lime waste $(\mathrm{LW})$ is used to activate a source alumina-silicate $(\mathrm{Al} / \mathrm{Si})$ materials offered by blend of metakaolin (MK) and a natural pozzolan material from volcanic tuff (NP).

\section{$2 \quad$ Materials and Experimental work}

\subsection{Material Characterisation}

Initially, all materials were assessed and characterised to evaluate their chemical and physical properties. Table 1 shows physical properties of materials including specific surface area, alkalinity and density. MK and NP having higher surface area than LW which has high alkalinity with $\mathrm{pH}$ of 12.3 which favourable for alkalination of MK and NP. Specific surface area was determined by Blaine Air Permeability Apparatus according to the British standard (EN 196-6). Mineralogy of materials was evaluated by X-Ray Diffraction (XRD) and Thermogravemetric analysis (TGA) methods. XRD has been conducted for undisturbed materials and after calcination with two levels $450{ }^{\circ} \mathrm{C}$ and $950{ }^{\circ} \mathrm{C}$.

Table 1. Physical properties of undisturbed materials.

\begin{tabular}{cccc}
\hline Material & $\begin{array}{c}\text { Specific surface area } \\
\text { (Blaine) }\left(\mathrm{m}^{2} / \mathrm{g}\right)\end{array}$ & $\mathrm{pH}$ & $\begin{array}{c}\text { Density } \\
\left(\mathrm{g} / \mathrm{cm}^{3}\right)\end{array}$ \\
\hline MK & 19.6 & 6 & 2.69 \\
NP & 17.2 & 6 & 2.57 \\
LW & 10.1 & 12.3 & 2.7 \\
\hline
\end{tabular}


Particle size distribution (PSD) was determined by laser diffraction particle size analyzer as displayed in Table 2. MK and NP were nearly similar with $\left(D_{50}\right)$ is 7.88 and $9.68 \mu \mathrm{m}$ respectively. Conversely, LW was coarser with $\mathrm{D}_{50} 15.9 \mu \mathrm{m}$.

Table 2. Particle size distribution (PSD) of starting materials.

\begin{tabular}{ccccccccc}
\hline & Amount & Mean & Median & S.D. & C.V. & d10 & d50 & d90 \\
\hline & $\%$ & $\mu \mathrm{m}$ & $\mu \mathrm{m}$ & $\mu \mathrm{m}$ & & $\mu \mathrm{m}$ & $\mu \mathrm{m}$ & $\mu \mathrm{m}$ \\
LW & 100 & 23.6 & 15.9 & 22.1 & $93.70 \%$ & 0.965 & 15.9 & 59.6 \\
MK & 100 & 13.9 & 7.88 & 15.2 & $110 \%$ & 1.2 & 7.88 & 38 \\
$\mathrm{NP}$ & 100 & 15.1 & 9.68 & 14.5 & $95.70 \%$ & 0.972 & 9.68 & 39 \\
(Average) & 100 & 17.5 & 11.2 & 17.3 & $99.60 \%$ & 1.05 & 11.2 & 45.5 \\
(C.V.) & $0.00 \%$ & $30.20 \%$ & $37.90 \%$ & $24.50 \%$ & $8.70 \%$ & $12.80 \%$ & $37.90 \%$ & $26.80 \%$ \\
(Maximum) & 100 & 23.6 & 15.9 & 22.1 & $110 \%$ & 1.2 & 15.9 & 59.6 \\
(Minimum) & 100 & 13.9 & 7.88 & 14.5 & $93.70 \%$ & 0.965 & 7.88 & 38 \\
\hline
\end{tabular}

All materials were provided from local suppliers in the UK. Materials were characterised chemically to determine their composition by using X-Ray fluorescence (XRF) as shown in Table 3. MK and $\mathrm{NP}$ are mostly composed of $\mathrm{SiO}_{2}$ and $\mathrm{Al}_{2} \mathrm{O}_{3}$ with less amounts of $\mathrm{CaO}, \mathrm{Na}_{2} \mathrm{O}, \mathrm{K}_{2} \mathrm{O}$ and $\mathrm{MgO}$ in NP. In contrast, $\mathrm{LW}$ is mostly rich of $\mathrm{CaO}$ of 80.1 Wt. \% with small amounts of $\mathrm{SiO}_{2}$ and $\mathrm{Na}_{2} \mathrm{O}$.

Table 3. Chemical composition of undisturbed materials by XRF.

\begin{tabular}{llll}
\hline Component & MK & NP & LW \\
\hline $\mathrm{SiO}_{2}$ & 46.2 & 46.6 & 14.6 \\
$\mathrm{Al}_{2} \mathrm{O}_{3}$ & 33 & 18.6 & 0.27 \\
$\mathrm{Fe}_{2} \mathrm{O}_{3}$ & 0.9 & 3.8 & 0.1 \\
$\mathrm{CaO}$ & 0.3 & 4.5 & 80.1 \\
$\mathrm{Na}_{2} \mathrm{O}$ & 0.9 & 3.9 & 1.8 \\
$\mathrm{~K}_{2} \mathrm{O}$ & 0.4 & 6 & 0.5 \\
$\mathrm{MgO}$ & 0.1 & 4.2 & 0.6 \\
$\mathrm{TiO}_{2}$ & 1.6 & 0.6 & 0.1 \\
\hline
\end{tabular}




\subsection{Tests preparation and procedures}

The mixing method was followed consistent with the requirements of (BS EN 196$1: 2016)$. Water/binder ratio $\mathrm{w} / \mathrm{b}$ was fixed of 0.45 for all the mortars after exploring the appropriate $\mathrm{w} / \mathrm{b}$ for the selected materials. Primarily, 0.55 ratio were chosen but it was found that the mortars were very workable. Consequently, it was decreased to 0.45 and mortars with suitable uniformity was attained at this stage. Mortars were mixed using sand passing through $2.0 \mathrm{~mm}$ BS sieve with a specific gravity of 2.62 with mixing ratio (1:2). The mortars were mixed using Hobart mixer and casted in steel moulds of prisms with $(40 \mathrm{~mm} * 40 \mathrm{~mm} * 160 \mathrm{~mm})$. Mortars were blended in ternary procedure with magnitudes as shown underneath in Table 4 . The mortars were cured in hot water curing regime to improve the reactivity and the hydration rate of the mortars and to avoid possible problems such as efflorescence and micro-cracking at this stage which can lead to reduction in compressive strength [7]. Curing temperature was fixed to $50{ }^{\circ} \mathrm{C}$ for 7 days and then cured in normal $20^{\circ} \mathrm{C}$ water until 28 days. This curing procedure was selected based on past reports and studies that proved the best curing temperatures for alkali activated cement $[8,9]$.

Calcination of materials in muffle furnace was individually to assess the influence of each material on the mixture's properties. Two levels of calcination were based $\left(950^{\circ} \mathrm{C}\right.$ and $450^{\circ} \mathrm{C}$ ) for $2 \mathrm{hrs}$ with $20^{\circ} \mathrm{C} / \mathrm{min}$ calcining rate. Calcination temperatures were chosen depending on the characterisation (XRD \& TGA) results which presented that most phase's changes take place at these levels.

Table 4. Mixing proportions of blends.

\begin{tabular}{ccc}
\hline Mix ID & Binder contents & Calcined constituent \\
\hline M1 & $35 \%$ MK 35\%LW 30\%NP & NP \\
M2 & $35 \%$ MK 35\%LW 30\%NP & MK \\
M3 & $35 \%$ MK 35\%LW 30\%NP & LW \\
M4 & $35 \%$ MK 35\%LW 30\%NP & NP, MK, LW \\
\hline
\end{tabular}

\section{$3 \quad$ Results and Discussions}

\subsection{Mineralogical Analysis}

It is noticeable from the diffractions of MK in Fig. 1 that MK encompasses of minerals comprising kaolinite and quartz in main phases. Minor phases involve of mullite, anatas and illite. Noteworthy decrease and even disappearance of kaolinite and quartz peaks were noted after both levels of calcination indicating semi-transformation of material to amorphous phase. 


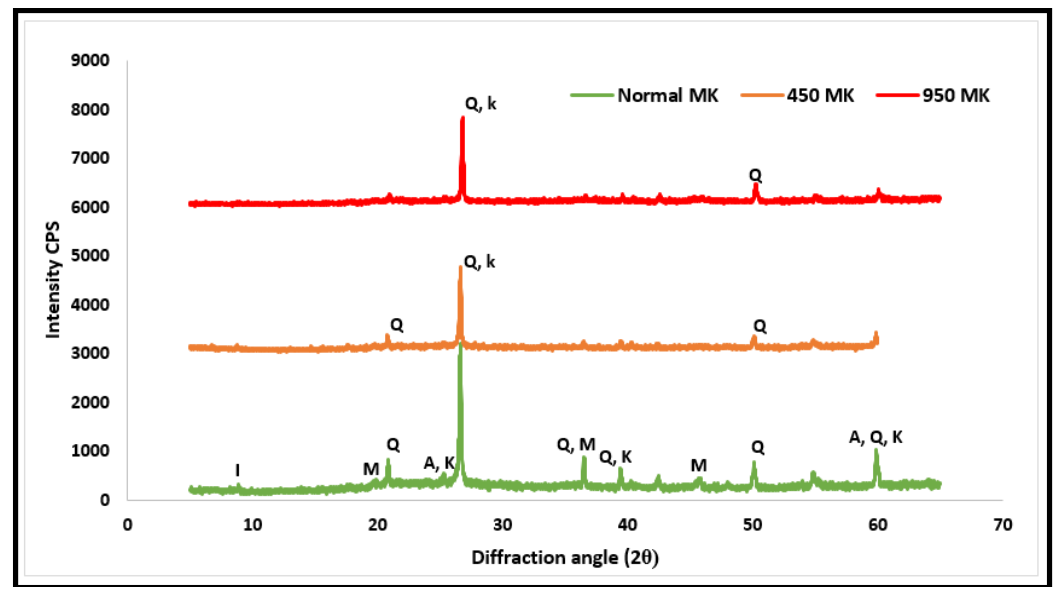

Fig. 1 XRD of MK before and after calcination.

Q: Quartz $\left(\mathrm{SiO}_{2}\right)$, K: kaolinite $\left(\mathrm{Al}_{2} \mathrm{Si}_{2} \mathrm{O}_{5}(\mathrm{OH})_{4}\right), \mathrm{M}$ : Mullite $\mathrm{Al}_{6} \mathrm{Si}_{2} \mathrm{O}_{13}$, A: Anatas $\left(\mathrm{TiO}_{2}\right)$, I: Illite $\left(\mathrm{K}, \mathrm{H}_{3} \mathrm{O}\right)(\mathrm{Al}, \mathrm{Mg}, \mathrm{Fe})_{2}(\mathrm{Si}, \mathrm{Al})_{4} \mathrm{O}_{10}\left[(\mathrm{OH})_{2},\left(\mathrm{H}_{2} \mathrm{O}\right)\right]$

In Fig. 2, XRD spectrums of NP which shows vast transformation of crystalline to amorphous phases through the loss of Clinoptilolite and Anorthite peaks. Moreover, substantial deceasing in crystalline quartz at $950{ }^{\circ} \mathrm{C}$ calcination level.

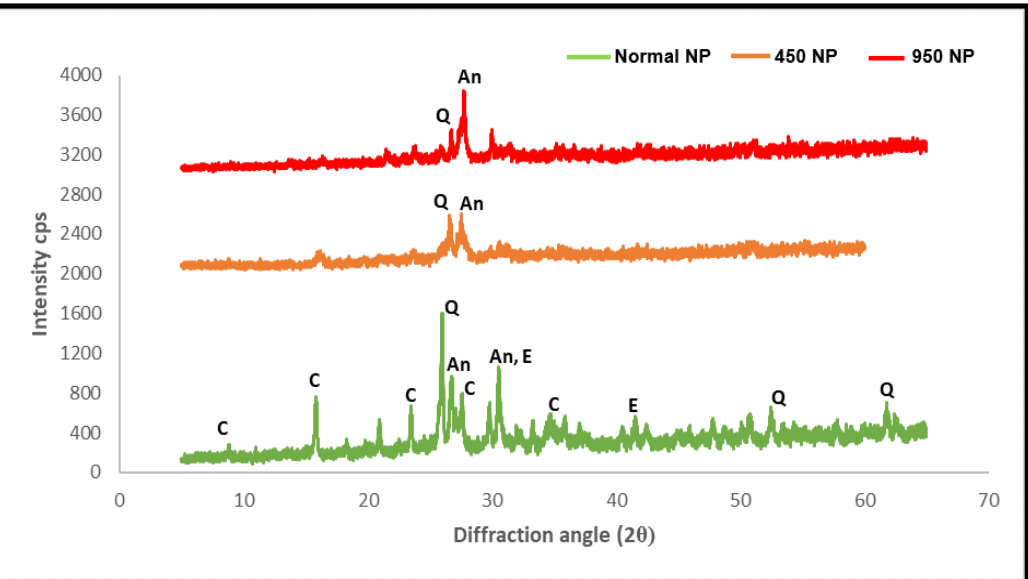

Fig. 2 XRD of NP before and after calcination.

Q: Quartz $\left(\mathrm{SiO}_{2}\right)$, C: Clinoptilolite $\left(\mathrm{KNa}_{2} \mathrm{Ca}_{2}\left(\mathrm{SiO}_{29} \mathrm{Al}_{7}\right) \mathrm{O}_{72} 24 \mathrm{H}_{2} \mathrm{O}\right)$, An: Anorthite

$\left(\mathrm{CaAl}_{2} \mathrm{Si}_{2} \mathrm{O}_{8}\right)$, E: Edenite $\left(\mathrm{Ca}_{2} \mathrm{NaMg}_{5}\left(\mathrm{AlSi}_{7}\right) \mathrm{O}_{22}(\mathrm{OH})_{2}\right)$

Fig. 3 displays the diffraction patterns of LW which it can be seen clearly that the strong crystalline diffraction peak of lime $(\mathrm{CaO})$ in $\mathrm{LW}$ was reduced significantly when calcined to $450^{\circ} \mathrm{C}$ and entirely disappeared in $950^{\circ} \mathrm{C}$ calcination. The presence of new diffraction peaks at new angles of calcined $\mathrm{LW}$ at $950^{\circ} \mathrm{C}$ representing the formulation 
of new compounds but composed of same elements of undisturbed $\mathrm{LW}\left(\mathrm{CaO}, \mathrm{SiO}_{2}\right.$ and $\mathrm{Na}_{2} \mathrm{O}$ ) in form of wollastonite minerals $[10,11]$.

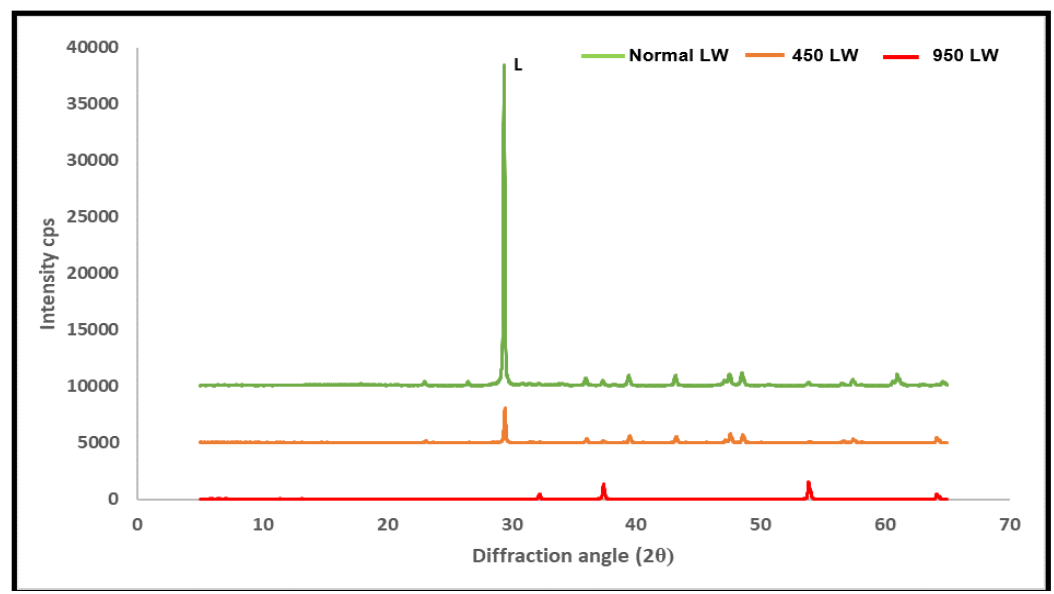

Fig. 3 XRD of LW before and after calcination

L: Lime $(\mathrm{CaO})$

\subsection{Thermogravemtric Analysis (TGA)}

TG-DTA thermal analysis was used to assess the thermal behaviour of raw materials when calcined to higher temperature up to $900^{\circ} \mathrm{C}$. Fig. 4A displays mass loss of NP up to $7 \%$ from initial weight when calcined from room temperature to $900^{\circ} \mathrm{C}$. While DTA curve is indicating exothermic concavity at $250^{\circ} \mathrm{C}$ tailed by endothermic drop in the curve reaching around $450^{\circ} \mathrm{C}$ representing a start of phase's conversion process at this temperature. DTA curve of MK has revealed minor phase change about $700^{\circ} \mathrm{C}$ as in Fig. 4B. Weight loss of LW started to drop intensely at $620^{\circ} \mathrm{C}$ with $35 \%$ from original weight with intense and severe exothermic peak of DTA curve as demonstrated in Fig. 4C. This peak accredited to disappearance of $(\mathrm{CaO})$ crystalline peak in XRD of calcined LW. 


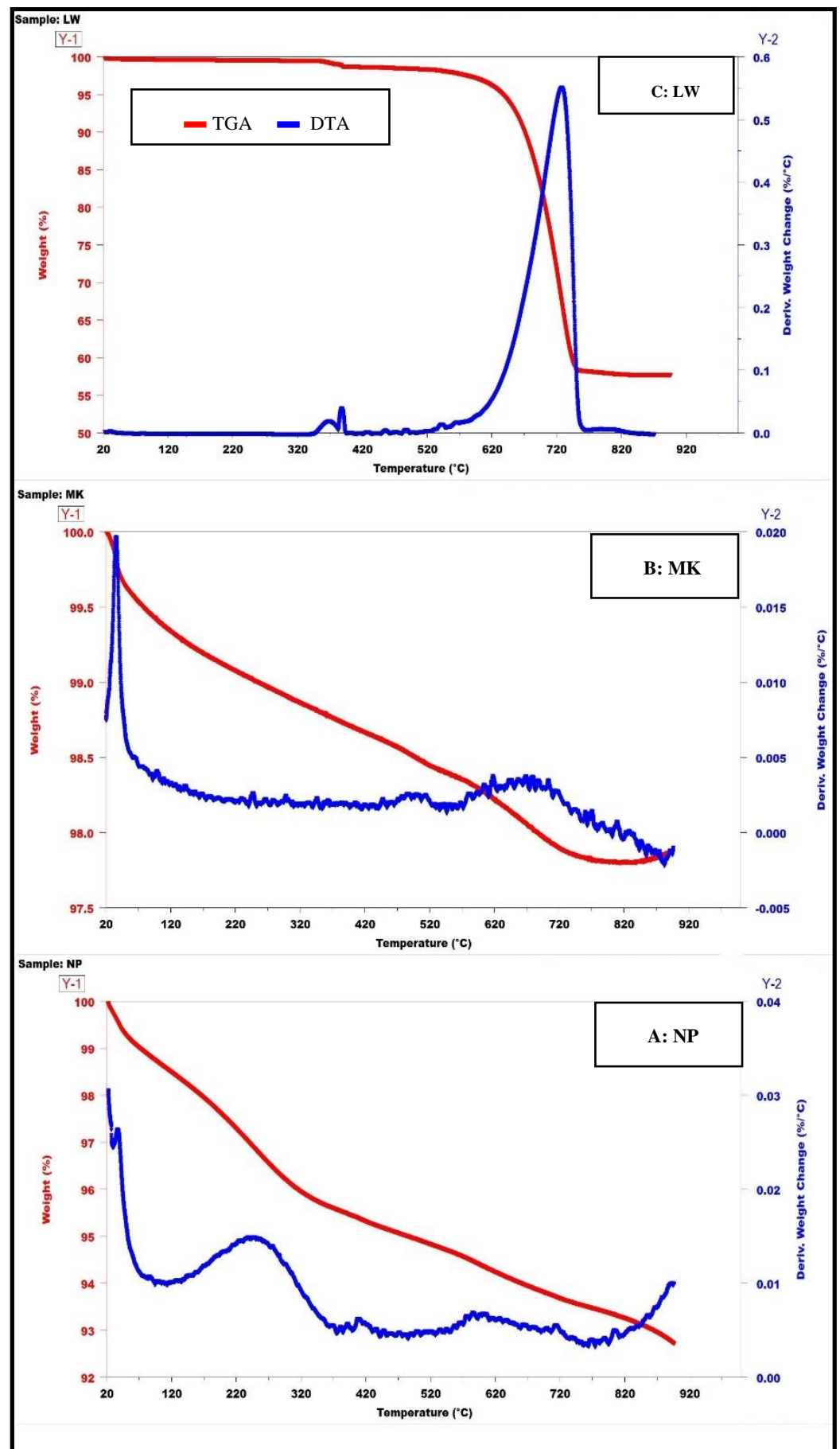

Fig. 4 TG-DTA analysis of A: NP, B: MK, C: LW 


\subsection{Compressive strength}

Fig. 5 is showing compressive strength of mortars after individual calcination for $950^{\circ} \mathrm{C}$. Higher strength was gained from M3 that consists of calcined LW with 27.3 $\mathrm{MPa}$ in 28 days. This strength is attributed to the large transformation to vitreous mineralogy and disappearance of crystalline $\mathrm{CaO}$ peak because of calcination to $950{ }^{\circ} \mathrm{C}$. Reduced dissolution of alumina-silicate compounds from NP and MK due to high amounts of amorphous compounds and lesser amounts of $\mathrm{CaO}$ when all materials calcined led to fall of strength in M4.

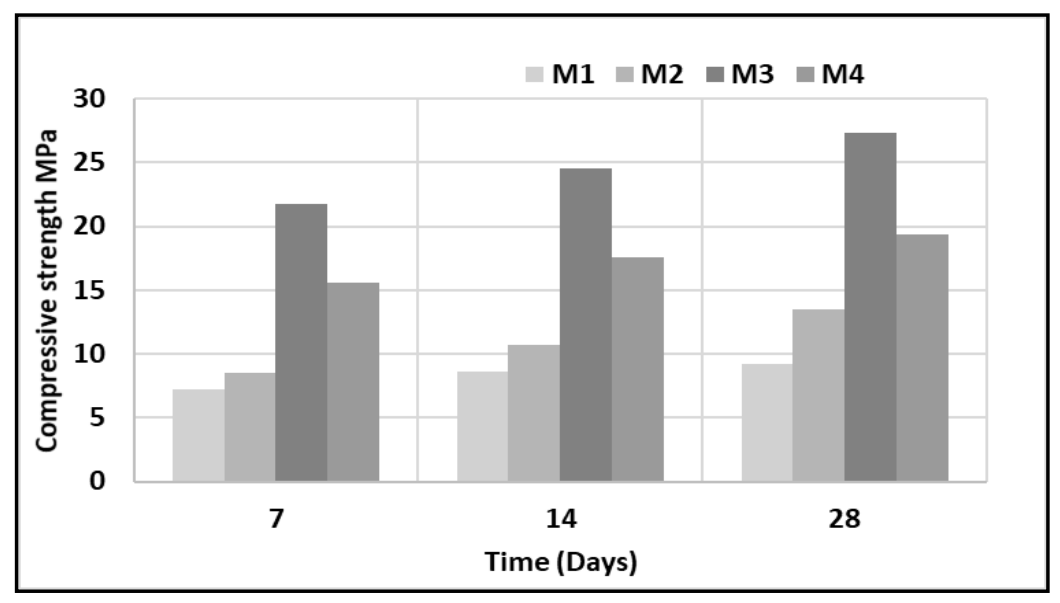

Fig. 5 Compressive strength after $950{ }^{\circ} \mathrm{C}$ calcination.

Both of XRD and TG-DTA results have shown that changes of phases of this ternary blend components starting in temperatures ranging from $350-500^{\circ} \mathrm{C}$. Hence, blends were mixed after calcination of $450{ }^{\circ} \mathrm{C}$ with same method of proportioning that mentioned in Table 4 above. Noticeably as shown below in Fig. 6, comparative strength was obtained at this level of calcination with developed strength reached for $25.6 \mathrm{MPa}$ at $28 \mathrm{~d}$ for M3-450 that has LW of 35\%. This comparable growth of strength is attributed to mineralogical and chemical variations that were remarked in both XRD and DT-TGA results which designated that most of diffraction patterns were starting to convert before and around $450{ }^{\circ} \mathrm{C}$. 


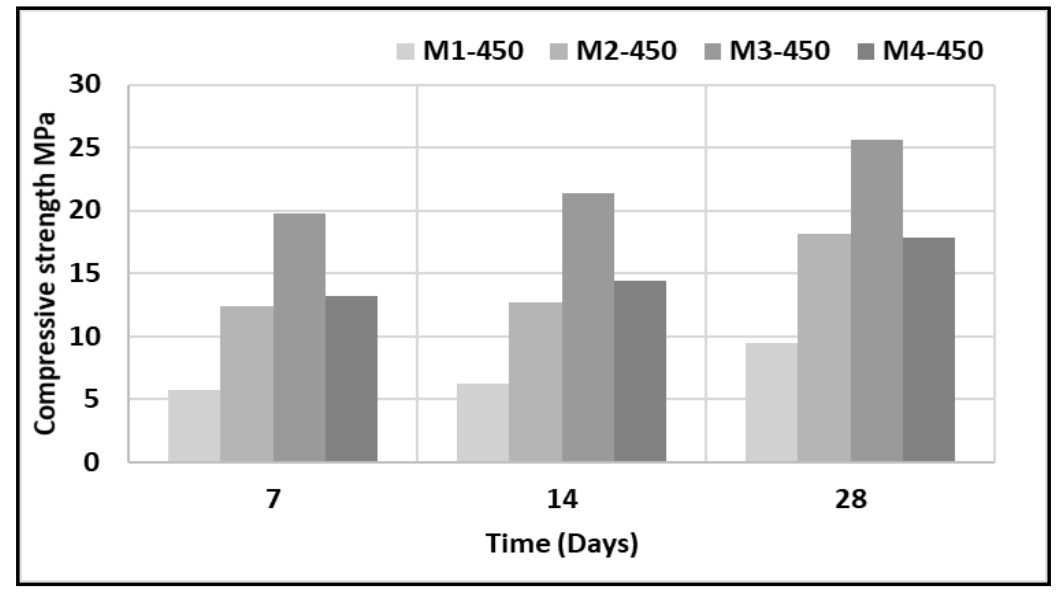

Fig. 6 Compressive strength after $450{ }^{\circ} \mathrm{C}$ calcination.

\section{Conclusions}

- $\quad$ Calcination was chosen assisted thermal activation for producing one part AAC from combination of alkali alumina silicate materials. Calcination of materials was conducted to $450{ }^{\circ} \mathrm{C}$ and $950{ }^{\circ} \mathrm{C}$ individually to assess the contribution of each material.

- $\quad$ Raw materials were characterised physically and chemically. Mineralogy and thermal behaviour and change due to calcination were assessed.

- Maximum compressive strength was recorded of $27.3 \mathrm{MPa}$ in $28 \mathrm{~d}$ for mortar containing calcined (LW) of $950{ }^{\circ} \mathrm{C}$. Relative compressive strength was gained at $450{ }^{\circ} \mathrm{C}$ calcination level demonstrating that reactivity of materials started to increase at this temperature.

- This strength growth was attributed to the massive conversion of LW mineralogy to be amorphous which initiated by calcination which evidently was considered as assisted activation factor.

- $\quad$ The outcomes of the study have showed that lime waste (LW) has high probability to be solid alkaline activator if treated correctly and its impurities are removed. 


\section{References}

1. Palomo, A., et al., A review on alkaline activation: new analytical perspectives. 2014, 2014. 64(315).

2. Provis, J.L., Alkali-activated materials. Cement and Concrete Research, 2017.

3. Luukkonen, T., et al., One-part alkali-activated materials: A review. Cement and Concrete Research, 2018. 103: p. 21-34.

4. Sturm, P., et al., Synthesizing one-part geopolymers from rice husk ash. Construction and Building Materials, 2016. 124: p. 961-966.

5. Vaccari, M., F. Gialdini, and C. Collivignarelli, Study of the reuse of treated wastewater on waste container washing vehicles. Waste management, 2013. 33(2): p. 262-267.

6. Kim, M.S., et al., Use of $\mathrm{CaO}$ as an activator for producing a price-competitive non-cement structural binder using ground granulated blast furnace slag. Cement and Concrete Research, 2013. 54: p. 208-214.

7. Chithra, S. and G. Dhinakaran, Effect of hot water curing and hot air oven curing on admixed concrete. International Journal of ChemTech Research CODEN (USA): IJCRGG, 2014: p. 1516-1523.

8. Perera, D.S., et al., Influence of curing schedule on the integrity of geopolymers. Journal of Materials Science, 2007. 42(9): p. 3099-3106.

9. Singh, B., et al., Geopolymer concrete: A review of some recent developments. Construction and Building Materials, 2015. 85: p. 78-90.

10. Eilers, L.H., E.B. Nelson, and L.K. Moran, High-Temperature Cement Compositions Pectolite, Scawtite, Truscottite, or Xonotlite: Which Do You Want? Journal of Petroleum Technology, 1983. 35(07): p. 1373-1377.

11. Garbev, K., et al., First Observation of $\alpha-\mathrm{Ca} 2[\mathrm{SiO} 3(\mathrm{OH})](\mathrm{OH})-\mathrm{Ca} 6[\mathrm{Si2O} 7][\mathrm{SiO} 4](\mathrm{OH}) 2$ Phase Transformation upon Thermal Treatment in Air. Journal of the American Ceramic Society, 2008. 91(1): p. 263-271. 